\title{
YIELD AND QUALITY OF SOME SUGAR BEET VARIETIES AS AFFECTED BY HARVEST DATE UNDER EL-MINIA GOVERNORATE CONDITION El-Bakary, H.M.Y.
}

Sugar Crops Res. Inst., Agric. Res. Center, Giza, Egypt

Key Words: sugar beet varieties, harvest dates.

ABSTRACT

A field experiment was carried out at Malawi Research Station, ElMinia governorate (latitude $28.10^{\circ} \mathrm{N}$, longitude $30.75^{\circ} \mathrm{E}$ and altitude of $55 \mathrm{~m}$ above sea level) Egypt in 2016/2017 and 2017/2018 seasons to evaluate the performance yield and quality of four multi-germ sugar beet varieties namely (Dina, Belatos, Athos poly and Sirona) under three harvesting dates being (180, 195 and 210) days from sowing. A splitplot design with three replications was used in both seasons.

The results showed that harvesting sugar beet after 210 days from sowing was the proper dates to obtain the highest root and foliage fresh weights /plant, sucrose, extractable sugar percentages, quality index, root and sugar yields/fed in both seasons. Compared to the other two dates (180 and 195) days from sowing.

Sowing Sirona variety led to an increase in root and sugar yields/fed than that recorded by Dina, Belatos and Athos poly varieties in the 1st and 2nd season, respectively. On the other hand, the highest values impurities (sodium and alpha-amino $\mathrm{N}$ contents) of Belatos and Athos poly were recorded by Dina variety which attained the lower values of potassium and sugar lost to molasses \%.

Delaying harvesting Sirona variety up to 210 days recorded the highest values of sucrose; extractable sugar percentages, root and sugar yield/fed in both seasons. Harvesting Belatos and Athos poly varieties at 180 and 195 days achieved the highest values of impurities (sodium, potassium and alpha-amino $\mathrm{N}$ contents) and sugar lost to molasses\% in both seasons.

\section{INTRODUCTION}

Sugar beet seeds sown in Egypt are imported and hence beet varieties should be evaluated under the Egyptian conditions to select the best varieties in respect to yield and quality traits. In this regard, Abd ElAal et al., (2010) revealed that a significant variation in yield productivity and root quality among sugar beet varieties. Kawemira and Gloria varieties gave the highest sugar yield followed by Nejma on the other hand Lola exhibited the lowest sugar yield. Oscar poly, Carola, 
Raspoly, Kawemera and Mont Bianko were more responsive to added nitrogen fertilizer. Shalaby et al., (2011) indicated that sugar beet varieties gave a significant increase for root fresh weight (g/plant), sucrose $\%$ as well as, root yield and sugar yield (tons/fed) in both seasons. While, sodium \%, potassium \% decreased significantly in both seasons. However, root diameter in the 2 nd season only. The interaction was significant in seasons for root fresh weight (Kg/plant, sucrose $\%$, root and sugar yield (tons/fed). Enan et al., (2016) indicated that the tested three beet varieties differed significantly in the studied traits. They added that the Polat variety showed superiority over the other two tested varieties and recorded the highest values of root diameter, fresh, and top weights/plant in both seasons. Meanwhile, insignificant differences were found between Polat and Henrike varieties in root diameter and top fresh weight/plant in the 1st season; root fresh weight/plant in the second one. Moreover, insignificant differences among varieties were detected in their impact on gross and corrected sugar yields/fed. Ahmed et al., (2017) stated sugar beet varieties differed significantly in all studied traits. Hosam variety was superior in root length, root yield/fed and root fresh weight/plant in both seasons. However, Kawemira variety had the thickest root diameter and heaviest top fresh weight/fed in both seasons. Sahar variety attained the highest values of sucrose and sugar yield/fed in both seasons purity\% in the 2nd one.Gobarah et al., (2019) indicated that the variances due to sugar beet varieties were significant in all studied traits. Ras-Poly variety recorded the highest values of root dimension, fresh weight /plant, sucrose, purity, and recoverable sugar percentages, as well as root and sugar yields/fed, followed by Dema-poly and Gloria varieties in descending order in both seasons. While Gloria variety produced the maximum top yield/fed. El-Mansuop et al., (2020) reported that the Kawemira variety had the tallest, heaviest roots and recorded the highest values of sucrose, extractable sugar percentages and yields of root and sugar/fed, while it gave less sodium and alpha-amino $\mathrm{N}$ contents.

Time of harvest is one of the main factors affecting yield and quality expected root and sugar yields of sugar beet crop. Some sugar beet genotypes have been promoted as high sugar content ones and are adapted for early harvest. In this connection, Jozef yova et al., (2004) reported that the postponement of the time of harvest by 27 days increased average root yield by $11.35 \mathrm{t} / \mathrm{ha}$. They also concluded that white sugar yield increased by delay in harvest by $1.69 \mathrm{t} / \mathrm{ha}$. Aly (2006) harvested sugar beet at age of 180,190 and 210 days and he found that delaying harvest dates up to 210 days from sowing increased significantly root diameter, sucrose $\%$, root and sugar yields/fed. Mahmoud et al., (2008) mentioned that the highest values of root and 
sugar yields/fed were obtained when sugar beet was harvested at 180-210 days after sowing. They added that varying varieties and harvesting dates affected sucrose and juice purity percentage, root and sugar yields/fed. Enan et al., (2011) reported that harvesting beet plants after 210 days from sowing were the proper age to obtain the highest sucrose and purity percentages as well root and sugar yields/fed. Shalaby et al., (2011) delaying harvesting dates from 180 to 210 days from sowing significantly increased root fresh weight $(\mathrm{Kg}) /$ plant, sucrose $\%$, as well as root and sugar yield (tons/fed). While, nitrogen $\%$, sodium $\%$, potassium $\%$ were decreased significantly in both seasons. Harvesting dates at 195 days from sowing gave the highest values. Aly et al., (2012) and found that late harvesting of sugar beet (210 days after sowing) gave the highest root diameter, sucrose $\%$, quality index, root (and sugar yields compared with harvesting it at 180 days after sowing. Mohamed and Yasin (2013) reported that delaying the harvesting date up to 210 days after sowing significantly increased yields of root and sugar/fed, compared with 180 days. Ahmed et al., (2017) delaying harvesting from 180 up to 210 days from sowing increased significantly root length, diameter and root fresh weight/plant, sucrose \%, root and sugar yields/fed in both seasons in the 1st season. Gadallah et al., (2017) indicated that delaying harvesting from 180 up to 210 days from sowing increased significantly root diameter, fresh weight/plant, sucrose $\%$, root and sugar yield/fed in both seasons. Nagib et al., (2018) showed that harvest age exhibited a significant effect on most studied traits in both seasons. Beets harvested age at 210 days after sowing surpassed those harvested earlier (180 days after sowing) in most traits in both seasons, except sugar lost to molasses \% and alpha-amino-N content.

\section{MATERIALS AND METHODS}

Field experiments was carried out at Malawi Research Station, ElMinia governorate (latitude $28.10^{0} \mathrm{~N}$, longitude $30.75^{\circ} \mathrm{E}$ and altitude of $55 \mathrm{~m}$ above sea level) Egypt in 2016/2017 and 2017/2018 seasons to evaluate the performance of four multi-germ sugar beet varieties namely (Dina, Belatos, Athos poly and Sirona) under three harvesting dates being (180, 195 and 210) days from sowing. A split- plot design with three replications was used in both seasons, where the main plots were devoted for harvest dates while sugar beet varieties were randomly distributed in the sub-plots. The plot area was $21.6 \mathrm{~m}^{2}$ including 6 ridges of $6-\mathrm{m}$ in length and $60-\mathrm{cm}$ in width, with $20-\mathrm{cm}$ hill spacing. Phosphorous fertilizer was added in the form of superphosphate $(15 \%)$ at the rate of $30 \mathrm{~kg} \mathrm{P}_{2} \mathrm{O}_{5}$ /fed during seedbed preparation. Nitrogen fertilizer was added in the form of ammonium nitrate $(33.5 \% \mathrm{~N})$ at the rate of 90 $\mathrm{kg} \mathrm{N} / \mathrm{fed}$ in two equal doses; after thinning (4 true leaf stage) and one month later. Potassium fertilizer was added in the form of potassium 
sulfate $(48 \%)$ at the rate of $48 \mathrm{~kg} \mathrm{~K}_{2} \mathrm{O} /$ fed with the second dose of nitrogen fertilizer. The country of origin of the tested sugar beet varieties is manifested in Table 1. As shown by Piper (1955), soil samples were taken for mechanical and chemical analyses before sowing from a location at $0-30 \mathrm{~cm}$ depth from soil surface according to A.O.A.C. (2005) and all data were shown in Table (2).

Table 1: Country of origin and source* of the evaluated sugar beet (Beta vulgaris var. saccharifera, L.) Varieties

\begin{tabular}{|c|c|c|c|c|}
\hline \multirow{2}{*}{ No. } & \multirow{2}{*}{ Sugar beet Varieties } & \multirow{2}{*}{ Type of Seeds } & \multicolumn{2}{|c|}{ Origin } \\
\cline { 4 - 5 } & & Multigerm & Kuhn & Netherland \\
\hline 1 & Dina & Multigerm & Semences & France \\
\hline 2 & Belatos & Multigerm & Kuhn & Netherland \\
\hline 3 & Athos poly & Multigerm & Desprez & France \\
\hline 4 & Sirona & &
\end{tabular}

*Source: Sugar Crops Research Institute, Agricultural Research Centre, Giza, Egypt

Table 2: Physical and chemical analysis of the experimental soil

\begin{tabular}{|c|c|c|}
\hline \multicolumn{3}{|c|}{ El- Menia experimental site } \\
\hline Properties & $2016 / 2017$ & $2017 / 2018$ \\
\hline \multicolumn{3}{|c|}{ Partial soil distribution } \\
\hline Sand \% & 8.65 & 9.35 \\
\hline Silt \% & 50.45 & 48.52 \\
\hline Clay \% & 40.90 & 42.13 \\
\hline Soil texture & \multicolumn{2}{|c|}{ Silty Clay } \\
\hline EC $(d S / m)$ & 1.80 & 1.60 \\
\hline pH (1:2.5) & 8.10 & 8.00 \\
\hline Organic matter \% & 1.22 & 1.18 \\
\hline \multicolumn{3}{|c|}{ Cations (meq/l) } \\
\hline $\mathrm{Ca}^{* *}$ & 9.78 & 8.45 \\
\hline $\mathrm{Mg}^{\text {*** }}$ & 2.72 & 2.75 \\
\hline $\mathrm{Na}^{+}$ & 4.95 & 4.45 \\
\hline $\mathbf{K}^{+}$ & 0.24 & 0.23 \\
\hline \multicolumn{3}{|c|}{ Anions (meq/l) } \\
\hline $\mathrm{HCO}_{3}^{-}$ & 3.68 & 3.25 \\
\hline $\mathrm{Cl}^{-}$ & 5.80 & 4.90 \\
\hline $\mathrm{SO4}^{-}$ & 8.21 & 7.73 \\
\hline Available N (mg/kg soil) & 39.10 & 40.35 \\
\hline Available P (mg/kg soil) & 8.50 & 7.85 \\
\hline Available K (mg/kg soil) & 175 & 180 \\
\hline
\end{tabular}

Also, data of monthly maximum, minimum temperatures degrees and relative humidity\% were obtained from the meteorological stations (Table 3). 
Table 3: Monthly air temperature ${ }^{o} C$ and relative humidity $\%$ of ElMinia Governorate in 2016/2017 and 2017/2018 growing seasons

\begin{tabular}{|c|c|c|c|c|}
\hline \multirow{2}{*}{ Month } & \multicolumn{3}{|c|}{ Temperature $C$} & \multirow{2}{*}{$\begin{array}{c}\text { Relative } \\
\text { humidity \% }\end{array}$} \\
\hline & Maximum & Minimum & Average & \\
\hline \multicolumn{5}{|c|}{ 2016-2017 } \\
\hline Oct. & 31.90 & $\mathbf{1 7 . 8 0}$ & 24.85 & 46.00 \\
\hline Nov. & 26.20 & 13.30 & 19.75 & 48.90 \\
\hline Dec. & 18.70 & 6.90 & 12.80 & 57.60 \\
\hline Jan. & 18.10 & 4.70 & 11.40 & 52.40 \\
\hline Feb. & 20.60 & 5.70 & 13.15 & 47.70 \\
\hline Mar. & 25.20 & 9.70 & 17.45 & 36.90 \\
\hline Apr. & 30.80 & 13.80 & 22.30 & 29.20 \\
\hline May. & 35.30 & 18.50 & 26.90 & 26.30 \\
\hline \multicolumn{5}{|c|}{$2017-2018$} \\
\hline Oct. & 30.00 & 15.90 & 22.95 & 41.00 \\
\hline Nov. & 24.60 & 10.90 & 17.75 & 48.40 \\
\hline Dec. & 21.40 & 9.00 & 15.20 & 52.50 \\
\hline Jan. & 18.35 & 7.60 & 12.98 & 63.73 \\
\hline Feb. & 21.63 & 9.27 & 15.45 & 53.71 \\
\hline Mar. & 21.97 & 8.13 & 15.05 & 38.40 \\
\hline Apr. & 23.09 & 8.37 & 15.73 & 40.00 \\
\hline May. & 24.67 & 11.80 & 18.24 & 35.17 \\
\hline
\end{tabular}

*Source: report, Agro meteorological data ARC, Giza Egypt

\section{The recorded data:}

At harvest, a sample of ten plants was randomly collected from the middle rows of each plot to determine the following traits:

\section{A- Vegetative qualities:}

1. Root length (RL) (cm).

2. Root fresh weight (RFW) (Kg/plant).

3- Top fresh weight (T FW) (Kg/plant)

B- Quality and chemical constituents:

Samples of the twenty roots were randomly taken sent to Laboratory at Abu Qurqas Sugar Factory Egypt according to the procedures of Sugar Company. By Automated Analyzer, as described by Brown and Lilliand (1964). Alpha-amino-N was determined using Hydrogenation method according to Carruthers et al., (1962).

1. Sucrose percentage (Pol \%) (S\%) was estimated in fresh samples of sugar beet roots, using polar metrically according to the method described in A.O.A.C. (2005). Le-Docte (1927).

2. Impurities of juice, in terms of Sodium (Na) and Potassium (K) concentrations were estimated as meq $/ 100 \mathrm{~g}$ beet while $\alpha$-amino N (A $\mathrm{N})$ was determined using ninhydrin hydrindantin" method according to the method Cooke and Scott (1993) 
3. Extracted sugar \% (ES \%) was calculated using the following equation according to Cooke and Scott (1993)

Extracted sugar $\%=(\mathrm{Pol} \%-0.29)-0.343 *(\mathrm{~K}+\mathrm{Na})-\alpha-$ amino $\mathrm{N} *$ (0.0939)

4. Sugar loss to molasses \% $(\mathbf{S L M} \%)=(\mathrm{K}+\mathrm{Na}) * 0.343+(\mathbf{\& N} * 0.094)$ +0.29 .

5. Juice quality index (QI \%) was calculated according to Cooke and Scott (1993)

$\mathrm{QI} \%=$ Quality index $\%=$ extracted sugar $\%(\%) / \mathrm{Pol} \times 100$. using the following equation:

6. Root yield/fed (RY) (ton), which were determined on sub plot weight $(\mathrm{kg})$ and converted to tons/fed.

7. Sugar yield/fed (SY) (ton) was calculated according to the following method of Devillers (1988): Sugar yield/fed (ton) $=$ root yield/fed (ton) $x$ extracted sugar \% / 100

\section{Statistical analysis:}

All obtained data were statistically analyzed according to the technique of analysis of variance (ANOVA) for A split-plot design as published by Gomez and Gomez (1984) using (MSTAT-c) computer software package. The least significant difference (LSD) was used to test the differences between treatment means at 5\% level of probability as described by Snedecor and Cochran (1981).

\section{The varietal effect:}

\section{RESULTS AND DISCUSSION}

Data in Table 4 revealed that the tested sugar beet varieties differed significantly in all studied traits in the $1^{\text {st }}$ and $2^{\text {nd }}$ season except alphaamino $\mathrm{N}$ trait the $1^{\text {st }}$ season. Sugar beet Sirona variety surpassed the other varieties in root and top fresh weights/plant, sucrose, extractable sugar percentages and as well root and sugar yields/fed, while Dina variety was superior in root length in both seasons. Planting Sirona variety led to an increase in root yield/fed amounted to $(0.21,1.66$ and 0.76--ton roots/fed) and (0.45, 1.97 and 1.18 -ton roots/fed) than that recorded by Dina, Belatos and Athos poly varieties in the $1^{\text {st }}$ season and $2^{\text {nd }}$ season, respectively. At the same time, the values of sugar yield/fed had the same tendency where it, amounted to (0.19, 0.51 and 0.31-ton sugar/fed) and $(0.12,0.54$ and 0.40 ton-sugar/fed) than that recorded by Dina, Belatos and Athos poly varieties in the $1^{\text {st }}$ and $2^{\text {nd }}$ season, respectively. On the other hand, the lower values of sodium, potassium and alpha-amino $\mathrm{N}$ contents were recorded by Dina and Sirona but, in the second one, Dina variety attained the lower values of potassium while the Sirona variety gave the lowest values of sodium and alpha-amino $\mathrm{N}$. These results could be due to the variations among the tested varieties in these traits might be 
due to their gene make-up. This finding is in harmony with that obtained by Enan et al., (2016) and Gobarah et al., (2019).

Table 4: Effect of growth, yield and quality traits for sugar beet varieties in 2016/2017 and 2017/2018 seasons

\begin{tabular}{|c|c|c|c|c|c|c|c|c|c|c|c|c|}
\hline \multicolumn{13}{|c|}{ 2016/2017 season } \\
\hline Characters & \multicolumn{3}{|c|}{ Growth traits } & \multicolumn{2}{|c|}{$\begin{array}{l}\text { Yields/fed } \\
\text { (ton) }\end{array}$} & \multicolumn{3}{|c|}{$\begin{array}{c}\text { Impurities content } \\
\text { (meq/100 } \mathrm{g} \text { beet) }\end{array}$} & \multirow{2}{*}{$\underset{\%}{\text { SLM }}$} & \multicolumn{3}{|c|}{ Quality traits } \\
\hline Varieties & $\begin{array}{r}\text { RFW } \\
(\mathrm{Kg})\end{array}$ & $\begin{array}{l}\text { TFW } \\
(\mathrm{Kg})\end{array}$ & $\begin{array}{l}\mathbf{R L} \\
(\mathbf{c m})\end{array}$ & $\begin{array}{c}\mathbf{R Y} \\
\text { (fed) }\end{array}$ & $\begin{array}{c}\text { SY } \\
((\mathbf{f e d})\end{array}$ & $\mathbf{K}$ & $\mathbf{N a}$ & $\begin{array}{c}\alpha- \\
\mathbf{A N}\end{array}$ & & S\% & ES\% & QI\% \\
\hline Dina & 1.184 & 0.245 & 31.04 & 24.19 & 3.51 & 4.14 & 2.28 & 4.49 & 2.92 & 17.41 & 14.49 & 83.24 \\
\hline Belatos & 1.123 & 0.218 & 30.11 & 22.74 & 3.19 & 3.92 & 2.78 & 4.23 & 2.99 & 16.99 & 14.00 & 82.42 \\
\hline Athos poly & 1.166 & 0.257 & 29.19 & 23.64 & 3.39 & 3.87 & 2.53 & 4.30 & 2.89 & 17.22 & 14.33 & 83.20 \\
\hline Sirona & 1.207 & 0.269 & 28.42 & 24.40 & 3.70 & 3.12 & 2.31 & 3.96 & 2.53 & 17.69 & 15.16 & 85.70 \\
\hline LSD at $5 \%$ & 0.014 & 0.008 & 1.079 & 0229 & 0.043 & 0.210 & 0.154 & NS & 0.100 & 0.124 & 0.187 & 0.637 \\
\hline \multicolumn{13}{|c|}{$2017 / 2018$ season } \\
\hline Dina & 1.164 & 0.214 & 27.22 & 23.66 & 3.47 & 3.00 & 2.27 & 4.27 & 2.50 & 17.14 & 14.64 & 85.40 \\
\hline Belatos & 1.092 & 0.204 & 26.99 & 22.14 & 3.05 & 3.83 & 2.69 & 4.29 & 2.93 & 16.73 & 13.80 & 82.42 \\
\hline Athos poly & 1.157 & 0.213 & 26.08 & 22.93 & 3.19 & 3.96 & 2.60 & 4.18 & 2.93 & 16.84 & 13.91 & 82.55 \\
\hline Sirona & 1.218 & 0.239 & 25.83 & 24.11 & 3.59 & 3.70 & 2.15 & 4.13 & 2.69 & $\mathbf{1 7 . 5 8}$ & 14.89 & 84.72 \\
\hline LSD at $5 \%$ & 0.02 & 0.01 & 0.88 & 0.11 & 0.05 & 0.19 & 0.10 & 0.26 & 0.09 & 0.12 & 0.17 & 0.54 \\
\hline
\end{tabular}

\section{Harvesting date effect:}

The results shown in Table 5 illustrated that delaying harvest dates from 180 to 195 and 210 days from sowing gradually and significantly increased root fresh weight/plant, yields of root and sugar/fed, sucrose, extractable sugar percentages and quality index in both seasons. The increments in root and sugar yields/fed amounted to $(3.33 \%, 2.37 \%$-ton roots/fed) and (10.98\%, 6.43\%-ton sugar/fed) respectively, in 1st season compared with that those recorded when harvesting beets after180 and 195 days. However, these increases were $(2.34 \%, 2.04 \%$ ton roots/fed $)$ and $\left(11.67 \%, 8.26 \%\right.$-ton sugar/fed) successively in $2^{\text {nd }}$ season, compared with that those recorded by harvesting sugar beet plants after the earlier and middle date (180 and 195 days). These results may be due to the relative advantage of increasing duration to harvest on some mention traits could be attributed to more dry matter accumulation with the advance of plant age (Enan et al., 2011). Moreover, harvesting beet plants at age of 180 days resulted in the highest values of top fresh weights/plant, root length and potassium, sodium and alpha-amino $\mathrm{N}$ contents, as well as, sugar lost to molasses \% compared to their harvested at 210 days from sowing in both seasons. These results show that delaying the harvesting date reducing impurities, hence significantly improved the quality index of sugar beet roots in addition to this result is probably due to the increase in sucrose $\%$ as plant age to harvest increased. These results are in agreement with those reported by (Mohamed and Yasin, 2013 and Gadallah et al., 2017) 
Table 5: Effect of harvesting date on growth, yield and quality traits in2016/2017 and 2017/2018 seasons

\begin{tabular}{|c|c|c|c|c|c|c|c|c|c|c|c|c|}
\hline \multicolumn{13}{|c|}{$2016 / 2017$ season } \\
\hline Characters & \multicolumn{3}{|c|}{ Growth traits } & \multicolumn{2}{|c|}{$\begin{array}{c}\text { Yields/fed } \\
\text { (ton) }\end{array}$} & \multicolumn{3}{|c|}{$\begin{array}{c}\text { Impurities content } \\
\text { (meq/100 g beet) }\end{array}$} & \multirow{2}{*}{$\underset{\%}{\text { SLM }}$} & \multicolumn{3}{|c|}{ Quality traits } \\
\hline $\begin{array}{c}\text { Harvesting } \\
\text { dates }\end{array}$ & $\begin{array}{c}\text { RFW } \\
\text { (Kg) }\end{array}$ & $\begin{array}{l}\text { TFW } \\
\text { (Kg) }\end{array}$ & $\begin{array}{l}\mathrm{RL} \\
(\mathrm{cm})\end{array}$ & $\begin{array}{c}\text { RY } \\
\text { (fed) }\end{array}$ & $\begin{array}{c}\text { SY } \\
\text { (fed) }\end{array}$ & $\mathbf{K}$ & $\mathbf{N a}$ & $\begin{array}{c}\alpha- \\
A N\end{array}$ & & $\mathbf{S \%}$ & ES\% & QI \\
\hline 180 & 1.137 & 0.273 & 31.20 & 23.41 & 3.28 & 4.09 & 2.69 & 4.79 & 3.07 & 17.06 & 13.99 & 82.02 \\
\hline 195 & 1.177 & 0.239 & 30.88 & 23.63 & 3.42 & 3.74 & 2.53 & 4.34 & 2.85 & 17.30 & 14.45 & 83.50 \\
\hline 210 & 1.195 & 0.229 & 26.99 & 24.19 & 3.64 & 3.46 & 2.21 & 3.60 & 2.57 & 17.62 & 15.05 & 85.39 \\
\hline LSD at $5 \%$ & 0.012 & 0.011 & 0.878 & 0.140 & 0.030 & 0.122 & 0.143 & 0.219 & 0.059 & 0.080 & 0.117 & 0.378 \\
\hline \multicolumn{13}{|c|}{ 2017/2018 season } \\
\hline 180 & 1.128 & 0.230 & 28.13 & 23.01 & 3.17 & 4.07 & 2.58 & 4.71 & 3.01 & 16.75 & 13.74 & 81.99 \\
\hline 195 & 1.160 & 0.215 & 27.02 & 23.08 & 3.27 & 3.68 & 2.48 & 4.43 & 2.81 & 16.98 & 14.17 & 83.40 \\
\hline 210 & 1.184 & 0.208 & 24.45 & 23.55 & 3.54 & 3.13 & 2.24 & 3.52 & 2.46 & 17.48 & 15.02 & 85.92 \\
\hline LSD at $5 \%$ & 0.01 & 0.01 & 0.66 & 0.09 & 0.03 & 0.14 & 0.08 & 0.20 & 0.06 & 0.09 & 0.12 & 040 \\
\hline
\end{tabular}

\section{Significant Interaction effect:}

Concerning the interaction between plant age at harvest date and varieties in Table 6, the results showed that top fresh weight/plant, sucrose, extractable sugar percentages, quality index and sugar yield/fed as well as the impurities in terms of potassium, sodium, alpha-amino $\mathrm{N}$ and sugar lost to molasses\% in the first season.

The difference at harvested date 180 days from sowing Sirona variety surpassed the other varieties in top fresh weight followed Dena, Athos poly and Belatos varieties in the 1st season respectively. At harvest date, 195-day Athos poly was superior in top fresh weight at harvest date 210-day Dina and Sirona varieties wave superior in top fresh weight compared to the other varieties.

Sirona variety recorded the lowest value of potassium $\%$ at all harvesting date compared to the other varieties.

The difference in sodium and alpha-amino N contents of Dina, Sirona and Athos poly varieties were insignificant when harvested in 210 days, or the difference in alpha-amino N contents among Dina, Sirona and Athos poly did not reach to significant when at harvest date 210 day from sowing.

For sugar lost to molasses\%, it could be noted that the difference among Athos poly, Dina and Belatos varieties were insignificant when harvested at 180 and 195 days from sowing. Sirona variety recorded the lowest value of sugar lost to molasses\% followed Athos poly, Dina and Belatos varieties.

Delaying harvest age from 180 to 195 and 210 days gradually increased sucrose, extractable sugar percentages and quality index when harvesting all tested varieties.

Harvesting Sirona variety at 210 days recorded the highest values of sucrose, extractable sugar percentages, sugar yield/fed. The 
differences between varieties may be due to the gene make-up and surround climate (Table 3) as well as the balance of elements in the experimental soil (Table 2). These results are in line with that obtained by Ahmed et al. (2017) and Nagib et al., (2018).

Table 6: Effect of the interaction between harvesting dates and varieties on same traits of sugar beet in $2016 / 2017$ season

\begin{tabular}{|c|c|c|c|c|c|c|c|c|c|c|c|c|}
\hline \multicolumn{13}{|c|}{ 2016/2017 season } \\
\hline Characters & \multicolumn{3}{|c|}{ Growth traits } & \multicolumn{2}{|c|}{$\begin{array}{l}\text { Yields/fed } \\
\text { (ton) }\end{array}$} & \multicolumn{3}{|c|}{$\begin{array}{l}\text { Impurities content } \\
\text { (meq/100 g beet) }\end{array}$} & \multirow{2}{*}{$\begin{array}{c}\text { SLM } \\
\%\end{array}$} & \multicolumn{3}{|c|}{ Quality traits } \\
\hline $\begin{array}{c}\text { Harvesting } \\
\text { dates }\end{array}$ & $\begin{array}{l}\text { RFW } \\
(\mathbf{K g})\end{array}$ & $\begin{array}{l}\text { TFW } \\
\text { (Kg) }\end{array}$ & $\begin{array}{c}\mathbf{R L} \\
(\mathbf{c m})\end{array}$ & $\begin{array}{c}\text { RY } \\
\text { (fed) }\end{array}$ & $\begin{array}{c}\text { SY } \\
((\text { fed })\end{array}$ & $\mathbf{K}$ & $\mathbf{N a}$ & $\begin{array}{c}\alpha- \\
\text { AN }\end{array}$ & & $\mathrm{S} \%$ & ES\% & QI \\
\hline 180 & 1.137 & 0.273 & 31.20 & 23.41 & 3.28 & 4.09 & 2.69 & 4.79 & 3.07 & 17.06 & 13.99 & 82.02 \\
\hline 195 & 1.177 & 0.239 & 30.88 & 23.63 & 3.42 & 3.74 & 2.53 & 4.34 & 2.85 & 17.30 & 14.45 & 83.50 \\
\hline 210 & 1.195 & 0.229 & 26.99 & 24.19 & 3.64 & 3.46 & 2.21 & 3.60 & 2.57 & 17.62 & 15.05 & 85.39 \\
\hline LSD at $5 \%$ & 0.012 & 0.011 & 0.878 & 0.140 & 0.030 & 0.122 & 0.143 & 0.219 & 0.059 & 0.080 & 0.117 & 0.378 \\
\hline \multicolumn{13}{|c|}{$2017 / 2018$ season } \\
\hline 180 & 1.128 & 0.230 & 28.13 & 23.01 & 3.17 & 4.07 & 2.58 & 4.71 & 3.01 & 16.75 & 13.74 & 81.99 \\
\hline 195 & 1.160 & 0.215 & 27.02 & 23.08 & 3.27 & 3.68 & 2.48 & 4.43 & 2.81 & 16.98 & 14.17 & 83.40 \\
\hline 210 & 1.184 & 0.208 & 24.45 & 23.55 & 3.54 & 3.13 & 2.24 & 3.52 & 2.46 & 17.48 & 15.02 & 85.92 \\
\hline LSD at $5 \%$ & 0.01 & 0.01 & 0.66 & 0.09 & 0.03 & 0.14 & 0.08 & 0.20 & 0.06 & 0.09 & 0.12 & 040 \\
\hline
\end{tabular}

The results in Table 7 indicated that the interaction between harvesting date and varieties exerted a significant effect on the root and top fresh weights/plant, sucrose $\%$, extractable sugar $\%$, quality index, root and sugar yields/fed as well, potassium, sodium, alpha-amino $\mathrm{N}$ and sugar lost to molasses $\%$ in the $1^{\text {st }}$ and $2^{\text {nd }}$ season.

Sirona variety recorded the highest weight harvest dates compared to the other varieties while Belatos variety attained the lowest value of root fresh weight. The results cleared that the difference in root fresh weight/plant of Dina and Athos poly varieties was insignificant when harvested at ages of 195 and/or 210 days.

At the same time, the difference in top fresh weight/plant of Belatos and Athos poly varieties were insignificant when harvested at ages of 195 and 210 days.

Sirona, Dina and Belatos varieties attained the highest root and the difference between them did not reach to a significant level.

Sirona variety surpassed the other Varieties in root yield at all harvesting dates.

For quality traits, it is noticed the Dina and Sirona varieties recorded the highest values of sucrose $\%$, extractable sugar $\%$ and, quality at harvest date 210 days from sowing and the difference between them did not reach to the significant level.

Generally delaying plant age at harvesting up to 210 days positively increased root, top fresh weights/plant, sucrose $\%$ extractable sugar $\%$, quality index, root and sugar yields/fed as well as, the lowest values of 
sodium, potassium, alpha-amino $\mathrm{N}$ contents and sugar lost to molasses\% when harvested Sirona variety had harvested in 210 days from sowing in the $2^{\text {nd }}$ season. These results are in harmony with those obtained by Mahmoud et al., (2008), Shalaby et al., (2011) and Alyet al., (2012).

Table 7: Effect of the interaction between harvesting dates and varieties on same traits of sugar beet in 2017/2018 season

\begin{tabular}{|c|c|c|c|c|c|c|c|c|c|c|c|c|}
\hline \multicolumn{2}{|c|}{ Characters } & \multicolumn{3}{|c|}{ Growth traits } & \multirow{2}{*}{$\begin{array}{c}\begin{array}{c}\text { Yields/fed } \\
\text { (ton) }\end{array} \\
\text { RY/fed) }\end{array}$} & \multicolumn{3}{|c|}{$\begin{array}{c}\text { Impurities content } \\
\text { (meq/100 g beet })\end{array}$} & \multirow{2}{*}{$\underset{\%}{\text { SLM }}$} & \multicolumn{3}{|c|}{ Quality traits } \\
\hline $\begin{array}{c}\text { Harvestin } \\
\text { g dates }\end{array}$ & varieties & $\begin{array}{r}\text { RFW } \\
(\text { Kg) }\end{array}$ & $\begin{array}{l}\text { TFW } \\
\text { (Kg) }\end{array}$ & $\begin{array}{c}\mathbf{R L} \\
(\mathbf{c m})\end{array}$ & & $\mathbf{K}$ & $\mathrm{Na}$ & $\begin{array}{c}\alpha- \\
\mathbf{A N}\end{array}$ & & S\% & ES\% & QI \\
\hline 180 day & \multirow{3}{*}{ Dina } & 1.135 & 0.210 & 29.17 & 23.33 & 3.80 & 2.03 & 4.53 & 2.72 & 16.75 & 14.03 & 83.78 \\
\hline 195 day & & 1.178 & \begin{tabular}{|l|l|}
0.227 \\
\end{tabular} & 27.15 & 23.38 & 2.77 & 2.57 & 4.17 & 2.51 & 17.10 & 14.59 & 85.32 \\
\hline 210 day & & 1.178 & 0.205 & 25.34 & 24.28 & 2.43 & 2.20 & 4.10 & 2.37 & 17.57 & 15.31 & 87.12 \\
\hline 180 day & \multirow{3}{*}{ Belatos } & 1.045 & 0.230 & 28.59 & 22.46 & 4.00 & 3.50 & 4.63 & 3.30 & 16.30 & 13.00 & 79.77 \\
\hline 195 day & & 1.107 & 0.190 & 27.67 & 21.92 & 3.97 & 2.27 & 4.87 & 2.88 & 16.61 & 13.72 & 82.62 \\
\hline 210 day & & 1.123 & 0.192 & 24.72 & 22.03 & 3.53 & 2.32 & 3.37 & 2.61 & 17.27 & 14.66 & 84.87 \\
\hline 180 day & \multirow{3}{*}{$\begin{array}{l}\text { Athos } \\
\text { poly }\end{array}$} & 1.158 & 0.235 & 27.57 & 22.61 & 4.37 & 2.63 & 5.03 & 3.16 & 16.45 & 13.29 & 80.77 \\
\hline 195 day & & 1.158 & 0.205 & 26.54 & 23.10 & 3.97 & 2.87 & 4.33 & 3.04 & 16.67 & 13.63 & 81.75 \\
\hline 210 day & & 1.155 & 0.200 & 24.13 & 23.09 & 3.53 & 2.30 & 3.43 & 2.59 & 17.40 & 14.81 & 85.12 \\
\hline 180 day & \multirow{3}{*}{ Sirona } & 1.175 & 0.235 & 27.18 & 23.63 & 4.10 & 2.13 & 4.63 & 2.86 & 17.52 & 14.65 & 83.66 \\
\hline 195 day & & 1.198 & 0.240 & 26.71 & 23.90 & 4.00 & 2.20 & 4.33 & 2.82 & 17.56 & 14.74 & 83.92 \\
\hline 210 day & & 1.280 & 0.243 & 23.61 & 24.81 & 3.00 & 2.12 & 3.17 & 2.26 & 17.66 & 15.29 & 86.58 \\
\hline \multicolumn{2}{|c|}{ LSD at $5 \%$} & 0.03 & 0.01 & 1.31 & 0.17 & 0.28 & 0.16 & 0.40 & 0.13 & 0.18 & 0.25 & 0.80 \\
\hline
\end{tabular}

\section{CONCLUSION}

Based on this, it is recommended to harvest the Sirona variety after 210 days of planting to obtain the maximum yields of root and sugar/fed under El-Minya conditions.

\section{REFERENCES}

Abd El-Aal, A.M. ; A.I. Nafie and R.M. Abdel Aziz (2010) Response of some sugar Beet genotypes to nitrogen fertilization under newly reclaimed land conditions. Egypt. J. Appl. Sci. 25 (6B) 194-208.

Aly- E.F. (2006) Effect of environmental conditions on productivity and quality Of some sugar beet varieties. Ph. D Thesis. Fac. Agric., Benha Univ.

Aly, M.S.M. (2012). Performance study of some sugar beet varieties under sowing and Harvesting dates. J. Plant Prod., Mansoura Univ. 3(9): 2439-2449.

A.O.A.C. (2005). Association of official analytical chemists. Official methods of Analysis, $26^{\text {th }}$ Ed. AOAC International, Washington, D.C; USA.

Ahmed.F.I. Gadallah et al. (2017) Effect of Harvesting Age of some Sugar Beet Varieties Grown in a New Reclaimed Soil in Sohag Alexandria Science Exchange Journal,38(4):975-982

Cooke, D.A. and R.K. Scott (1993). The Sugar Beet Crop. Science Practice. Puplished by Chapman and Hall, London. pp: 262-265. 
Devillers, P. (1988). Prevision du sucre melasse. Scurries francases 129, 190-200. (The Sugar Beet Crop Book, 572-574, 1st Edition published by Chapman and Hall, Univ. Press, Cambridge, UK).

Dexter, S.T.; M. Frankes and F.W. Snyder (1967). A rapid of determining Extractable white sugar as may be applied to the evaluation of agronomic Practices and grower deliveries in the sugar beet industry. J. Am., Soc., Sugar Beet Technol., 14: 433-454.

El- Mansoub M.M.A., A.H.Sasy and K.A.AbdEl-Sadek (2020) Effect of sowing date and nitrogen fertilization on powdery mildew disease, yield and quality of some sugar beet varieties. J. Biol. Chem. Environ. Sci., 15(2): 35-54.

Enan, S.A.A.M.; A. M. Abd El-Aal and N.M.E. Shalaby (2011). Yield and quality of some sugar beet varieties as affected by sowing date and harvest age. Faiyum J. Agric. Res. \& Dev., 25 (2): 51-65.

Enan, S.A.A.M.; E.F.A. Aly and A.I. Badr (2016). Effect of humic acid and potassium on yield and quality of some sugar beet varieties in sandy soil. J. Plant Prod., Mansoura Univ., 7 (2):289- 297.

Gadallah et al. (2017) Effect of Harvesting Age of some Sugar Beet Varieties Grown In a New Reclaimed Soil in Sohag Alexandria Science Exchange Journal, VoL.38, No.4, 975-982

Gomez, K.A. and A.A. Gomez (1984) Statistical Procedures for Agricultural Resear A Wiley-Inter-Science Publication, John Wiley and Sons, New York

Gobarah, Mirvat E. M.M. Hussein, M.M. Tawfik, Amal G. Ahmed, Manal F. Mohamed (2019) Effect of Different Sowing Dates on Quantity and Quality of Some Promising Sugar Beet (Beta vulgaris L.) Varieties under North Delta, Condition Egypt. J. Agron. 41(3): 343-354

Jozefyova, L., J. Pulkrabek and J. Urban (2004). Effect of harvest time on sugar Beet fertilized with increased nitrogen. J. Food Agric. Environ., 2: 232-237.

Le-Docte, A. (1927). Commercial determination of sugar beet in the beet roots using Sachs Le-Docte process. Int. Sugar J., 29: 488-492.

Mahmoud, S.A; B.H. I.H. El-Geddawy and D.T.A. Mosa (2008) Effect of sowing And harvest dates on yield and quality of some sugar beet varieties. Proc. Inter. Conf. (IS 2008), Al-Arish, Egypt. Sept. 11-14 pp 22-29.

Mohamed, Hanan Y. and M.A.T. Yasin (2013). Response of some sugar beet Varieties to harvesting dates and foliar application of Boron and Zinc in sandy Soils. Egypt. J. Agron., 35(2): 227-252.

Nagib, S. R. et al. (2018), Evaluation of some New Sugar Beet Varieties as Affected By Different Harvest Ages under Conditions of Minia Governorate J. Plant Production, Mansoura Univ., 9 (12): 1175 - 1180 
Piper, C.S. (1955). Soil and plant analysis. Univ., of Adelaide, Australia.178.

Shalaby, N.M.E. (2011) Evaluation of some sugar beet varieties as affected by Harvesting dates under newly reclaimed soil, Egypt. J. Agric. Res., 89 (2): 605- 614

Snedecor, G. W. and W. G. Cochran (1981). Statistical methods 6th Ed. Iowa State Univ. Press. Ames. Iowa. USA.

\section{تأثير ميعاد الحصاد علي حاصل وجوده بعض أصناف بنجر السكر تحت ظروف محافظة المنيا \\ حمدي محمد يوسف البقري$$
\text { معهد بحوث المحاصيل السكرية - مركز البحوث الزراعية - جيزة - مصر . }
$$

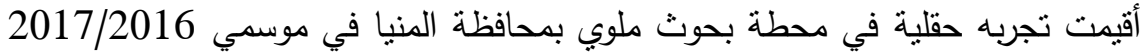

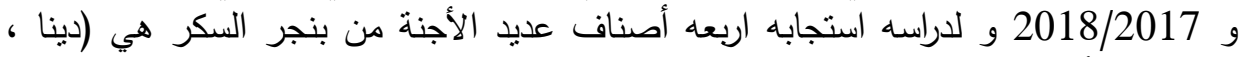

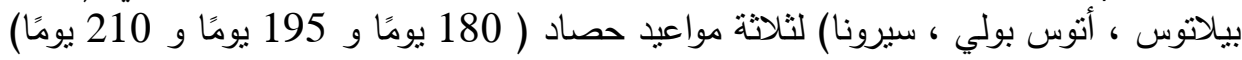

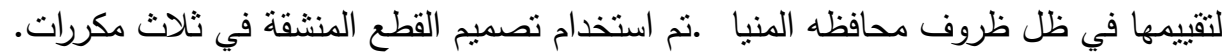
- أظهرت النتائج المتحصل عليها أن حصاد بنجر السكر بعد 210 يوم من الزراعة كان فئان

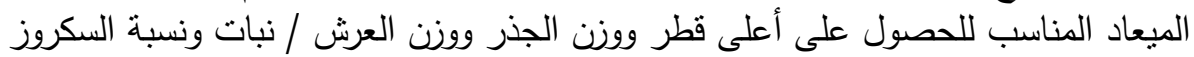
ونسبة السكر القابل للإستخراج، مؤشر الجولى الجودة وحاصل الجذور والسكر/فدان في كلان

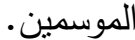

- أدت زراعة صنف سيرونا إلى زيادة حاصل الجذور والسكر / فدان عن تلك التي سجلتها

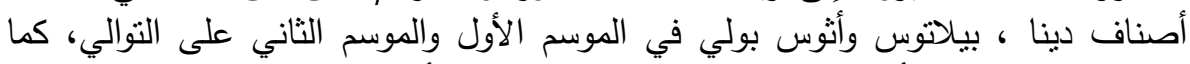

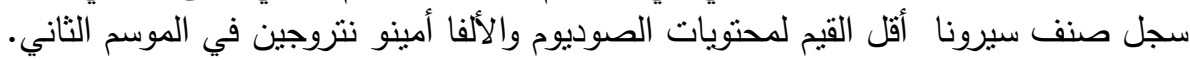

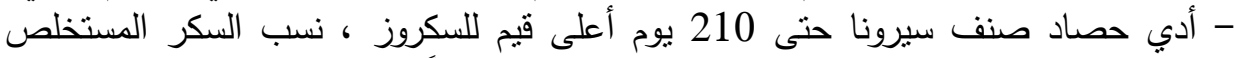

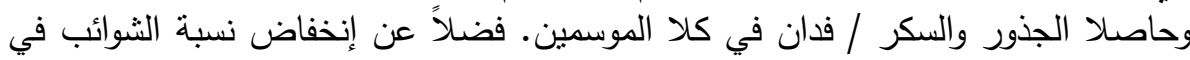

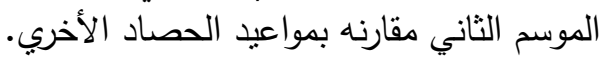

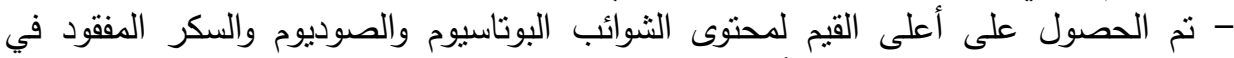

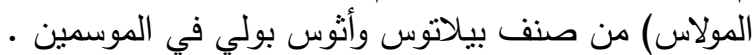

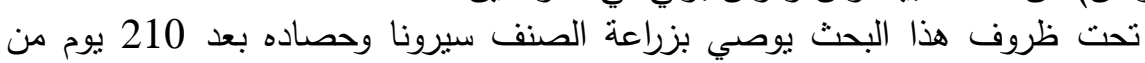

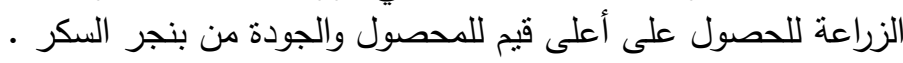

